\title{
Mahasiswi perokok: Studi fenomenologi tentang perempuan perokok di kampus
}

\author{
The Smoking Students: Phenomenology study of female smokers \\ in the campus
}

\author{
Fauzi Maulana Rizky Akbar \\ Departemen Sosiologi, Fakultas Ilmu Sosial dan Ilmu Politik, Universitas Airlangga \\ Surabaya, 60286, Jawa Timur, Indonesia \\ E-mail corresponding author: fauzi.maulana.rizky-2014@ fisip.unair.ac.id
}

\begin{abstract}
Abstrak
Di era ini, tidak hanya kaum laki-laki yang merokok melainkan kaum perempuan juga melakukannya. Perilaku merokok pada kaum perempuan juga menjadi suatu perdebatan mengenai keetisannya di kalangan masyarakat tertentu yang akhirnya menimbulkan berbagai anggapan. Perilaku merokok bahkan dilakukan oleh mahasiswi yang ada di lingkungan Universitas Airlangga Surabaya. Tujuan dari penelitian ini adalah untuk mengetahui makna perempuan tentang kebiasaan merokok yang dilakukan di lingkungan Universitas Airlangga Surabaya. Ada makna yang terkandung ketika mahasiswi tersebut saat merokok selain sebagai sebuah kebutuhan. Metode penelitian kualitatif dengan menggunakan pendekatan fenomenologi Alfred Schutz. Hasil penelitian menunjukkan bahwa mahasiswi tersebut merokok karena saat merokok dirinya dapat lebih percaya diri dan mempermudah saat menyelesaikan sebuah permasalahan. Perempuan ini memaknai rokok sebagai Pertama, rokok sebagai hubungan pertemanan karena rokok dapat mencairkan suasana ketika melakukan aktivitas sosial. Kedua, merokok sebagai kebutuhan. Merokok sudah tidak dapat ditinggalkan karena sudah menjadi sebuah ketergantungan. Ketiga, merokok sebagai lifestyle, karena hidup di daerah perkotaan sehingga merokok sudah bukan menjadi sesuatu yang tabu untuk dilakukan. Sebuah pemaknaan terhadap rokok bagi perempuan tidak terlepas dari adanya because of motive sebelum terjadinya in order to motive yang merupakan penyebab dari perempuan merokok dan tujuan mengapa mereka menjadi seorang perokok. Informan merasakan reaksi yang sama dalam lingkungan sosial yaitu menjadi perbincangan teman, diperolok oleh teman, bahan sindiran oleh dosen, penolakan oleh orang tua akan kegiatan merokok tersebut, hingga pembiaran yang dilakukan oleh keluarga karena telah mengganggap hal tersebut merupakan hal yang biasa terjadi di dalam lingkungan keluarganya.
\end{abstract}

Kata Kunci: perilaku merokok; mahasiswi; perempuan merokok; perilaku menyimpang; kampus

\begin{abstract}
Smoking does not only occur among men, but also among women. The act of smoking among women has become an issue of ethic within particular communities; one that leads to various assumptions. This is also the case in Universitas Airlangga Surabaya. This study aims to understand how these female students makes meaning from their act of smoking. Such meaning is important since smoking is more than just a necessity. This qualitative study employed phenomenological approach of Alfred Schutz. The results show that these female students smoke because it helps them feel more confident and aids better problem solvings. These female students also attach several meanings to the act of smoking. First, smoking helps in friendship since it helps to break the ice during social encounters. Second, smoking is a necessity since they are not able to quit because of the addiction. Third, smoking is part of the urban lifestyle; it is not a taboo. These meanings are inseparable from the 'because of' motives and the accompanying 'in order to' motives. In addition, the informants also experience the following responses from their social surroundings: becoming subjects of friends' talks, being ridiculed by friends, being subjects of insinuation by the lecturers, rejection of such activity from parents, and indifference from families accustomed to smoking.
\end{abstract}

Keywords: smoking behavior; college student; female smoking; deviant behavior; campus

\section{Pendahuluan}

Rokok telah dikenal masyarakat Indonesia bahkan jauh sebelum zaman kemerdekaan. Di kala itu, rokok hanyalah "rokok". Tidak ada konsekuensi moral atau pun etika meski perempuan yang mengkonsumsinya. Rokok menjadi hal yang dapat dan biasa saja dikonsumsi oleh semua orang tanpa memandang jenis kelamin. Namun kian diamati, lelaki menjadi ikon sebagai "pengguna rokok" dalam 
setiap iklan rokok di Indonesia. Merokok menjadi hal yang pantas dan wajar dilakukan kaum pria tanpa adanya berbagai macam penilaian negatif, sedang ketika perempuan merokok, pandangan aneh dapat terlontar dari mata masyarakat di sekitarnya (Ayu \& Syukur 2018; Purnomo 2020; Aditya 2019; Hagen et al. 2016). Berbagai penilaian moral miring sangat mudah terlontar bagi perempuan yang melakukan kegiatan merokok di depan umum. Anggapan buruk seperti perempuan "tidak benar", perempuan "nakal", perempuan "liar", bahkan perempuan "brandal" dapat mudah terbesit dalam benak masyarakat ketika melihat seseorang perempuan merokok. Terlebih lagi penggambaran wanita merokok dalam media yang cenderung negatif.

Budaya masyarakat di Indonesia secara implisit mengandaikan adanya stereotype tertentu mengenai perempuan dan laki-laki (Mustadjar 2013; Saguni 2014; Hentschel 2019; Ellemers 2018). Laki-laki dianggap sebagai individu yang memiliki sifat maskulin seperti kuat, dominan, rasional, dan sebagainya. Sedangkan perempuan dianggap memiliki sifat feminim, lembut, emosional, sensitif, penuh kasih sayang, dan sebagainya. Pemahaman mengenai adanya perbedaan antara laki-laki dan perempuan dalam masyarakat tersebut kemudian menimbulkan adanya pengelompokkan antara perilaku sosial dan perilaku anti-sosial, yaitu perilaku sesuai dan tidak sesuai, perilaku yang diharapkan dan tidak diharapkan dari laki-laki dan perempuan.

Perilaku merokok pada perempuan menjadi suatu perdebatan mengenai keetisannya di kalangan masyarakat tertentu yang akhirnya menimbulkan berbagai anggapan. Merokok dianggap bukan sesuatu yang lumrah dan lazim dilakukan oleh perempuan, karena perempuan yang merokok dianggap sebagai ciri khas yang akan membedakan mereka dari perempuan-perempuan lain yang tidak merokok.

Seiring dengan perkembangan masyarakat yang semakin modern, kebiasaan merokok pada saat ini bukan lagi menjadi hal yang dianggap tabu dalam kehidupan masyarakat. Di Kota Surabaya keberadaan perempuan yang merokok di depan umum menjadi pemandangan yang sering terjadi. Tingkat kebutuhan akan gaya hidup yang modern, membuat anggota masyarakat khususnya perempuan untuk mencoba hal-hal baru dalam hidupnya. Dalam hal ini tentu saja banyak faktor yang menyebabkan perempuan akhirnya memilih untuk mengkonsumsi rokok.

Dalam kaitannya dengan makna merokok pada mahasiswi motivasi yang mendasari mereka mengkonsumsi rokok di antaranya adalah ingin coba-coba, motivasi dari dalam diri sendiri setelah melihat orang lain merokok dan untuk menghilangkan stres. Dari berbagai motivasi yang mendasari mahasiswi untuk mengkonsumsi rokok dianalisis dengan teori-teori sosiologi dari "Paradigma Perilaku Sosial" yang memusatkan perhatiannya kepada hubungan antara individu dan lingkungannya. Hal ini berarti bahwa pengaruh dari faktor lingkungan yang membuat seorang mahasiswi kemudian memutuskan untuk menjadi perokok. Dalam hal ini, faktor lingkungan mempunyai cakupan yang luas, misalnya lingkungan teman sepergaulan, lingkungan keluarga bahkan lingkungan masyarakat dimana seseorang itu tinggal (Riyandi et al. 2017; Kim et al. 2010; Thiangtham et al. 2013; Komasari \& Helmi 2000; Septanto 2019).

Perempuan perokok sebagai suatu simbol atau istilah yang menunjuk pada suatu gaya hidup modern baik di perkotaan maupun perdesaan. Seiring perkembangan zaman, perilaku merokok yang umumnya dilakukan laki-laki, atau dianggap tabu bila dilakukan oleh perempuan, kini sudah berubah akibat pengaruh perubahan dalam masyarakat. Perilaku yang kebanyakan berasal dari hasil coba-coba ini kini sudah mulai menjadi gaya hidup atau tren yang hadir secara wajar dalam kehidupan masyarakat. Proses perubahan terjadi dalam masyarakat karena manusia adalah makhluk yang berfikir dan bekerja. Perubahan sosial dipandang sebagai suatu upaya modifikasi yang terjadi dalam pola- pola kehidupan manusia. Hal ini terjadi karena faktor intern maupun faktor ekstern. Dari berbagai faktor itulah yang menyebabkan suatu kondisi atau keadaan dimana kebiasaan merokok pada perempuan hadir sebagai suatu trend baru dan sudah tidak dianggap tabu lagi oleh sebagian besar rnasyarakat. Bahkan tren ini telah mengabaikan kesadaran mereka akan bahaya penggunaan rokok bagi perempuan (Lestari \& Demartoto 2012; Mutadhir \& Patasik 2018; Karini \& Padmawati 2018; Allen et al. 2014). 
Perubahan seperti ini juga dialami oleh perempuan perokok. Mereka yang dulunya tidak pernah mengkonsumsi rokok dan karena adanya pengaruh dari lingkungan yang menyebabkan mereka menjadi perokok aktif sarnpai sekarang. Perubahan yang terjadi pada perempuan perokok ini membutuhkan waktu yang tidak sebentar, dibutuhkan proses yang lama sarnpai mereka mengambil keputusan untuk mengkonsumsi rokok. Perubahan juga terjadi di lingkungan keluarga, rnasyarakat dan teman-temannya. Perubahan pola berfikir yang terjadi pada masyarakat modern ini disebabkan oleh interaksi masyarakat yang secara kontinyu kepada para perokok perempuan.

Banyak faktor menjadi penyebab seorang mahasiswi menjadi perokok (Lestari 2012; Snow \& Bruce 2003; Brahmana 2009; Wulandari 2007). Hampir semuanya menyatakan bahwa faktor lingkungan mempunyai andil yang sangat besar atas terbentuknya perilaku merokok dalam diri mereka. Misalnya faktor lingkungan pergaulan yang mampu merubah seorang yang bukan perokok menjadi perokok berat. Lingkungan pergaulan mempunyai pengaruh yang cukup kuat karena dalam kesehariannya seseorang selalu berinteraksi sosial dengan lingkungan pergaulan bersama teman-temannya.

Di samping lingkungan pergaulan, lingkungan keluarga juga turut mengambil bagian dalam hal pembentukan perilaku seseorang, dalam hal ini mahasiswi perokok. Terdapat beberapa mahasiswi perokok yang mengaku mulai tertarik untuk merokok setelah melihat sosok salah satu anggota keluarganya yang merokok. Sosok ini biasanya mempunyai pengaruh yang cukup kuat dalam diri individu tersebut. Di samping itu, faktor yang mendorong seseorang untuk mencoba hal-hal baru termasuk merokok juga tidak bisa dikesampingkan begitu saja. Banyak perokok yang awalnya hanya coba- coba, tetapi kini malah menjadi pecandu berat. Selanjutnya, terdapat individu yang keinginan merokoknya berasal dari dalam dirinya sendiri karena mempunyai banyak hal yang dipikirkan. Jadi kebiasaan merokok yang mereka lakukan itu untuk menghilangkan stres, menenangkan jiwa atau hanya sekedar mengusir kejenuhan saja (Buckner \& Vinci 2013; Mansouri et al. 2018).

Berbagai macam penyebab mahasiswi itu merokok akhirnya mereka mempunyai makna tersendiri ketika dirinya sudah menjadi perokok aktif atau perokok berat. Baginya merokok bukan hanya sekedar pengaruh orang tua, pengaruh lingkungan teman sebaya atau pun hanya sekedar keinginan mereka pribadi tetapi bagi mereka rokok bukan hanya sekedar rokok. Penelitian ini menggunakan teori fenomenologi Alfred Schutz, menurutnya peranan fenomenologi menjadi lebih penting, karena secara prakteknya fenomenologi di peruntukkan sebagai jiwa dari metode penelitian sosial dalam pengamatan terhadap pola perilaku seseorang sebagai aktor sosial dalam masyarakat (Schutz 1970).

Alfred Schutz memusatkan perhatiannya pada cara orang memahami kesadaran orang lain sementara mereka hidup dalam aliran kesadaran mereka sendiri. Pemahaman ini mereka peroleh dengan cara melakukan interaksi satu dengan yang lainnya yang akhirnya terjadi proses pemaknaan. Interaksi yang dimaksudkan yaitu terjadi antara individu dengan adanya industrialisasi yang ada di sekitar mereka, sehingga timbul suatu pemaknaan tersendiri terhadap industrialisasi itu. Proses ini dilakukan oleh individu tidak lain adalah untuk membangun dirinya sendiri. Dunia ini merupakan konstruksi individu terhadap keadaan lingkungan ekstern dan intern individu, sehingga dalam proses pemaknaan tersebut diawali dengan arus pengalaman (stream of experience) yang berkesinambungan dan diterima oleh panca indra. Schutz juga berpendapat bahwa tindakan manusia menjadi suatu hubungan sosial bila manusia memberikan arti atau makna tertentu terhadap tindakan itu, dan manusia lain memahami pula tindakannya itu sebagai sesuatu yang penuh arti. Selain juga menjelaskan tiga unsur pengetahuan yang membentuk pengertian manusia tentang masyarakat, yaitu dunia sehari-hari, sosialitas, dan makna.

Schutz menyatakan bahwa fenomenologi merupakan cara individu untuk memahami kesadaran dan tindakan manusia. Tindakan- tindakan subjektif para aktor, tidak muncul begitu saja melainkan melalui suatu proses yang cukup panjang untuk dievaluasi dengan selalu mempertimbangkan kondisi sosial, ekonomi, budaya dan norma etika agama atas dasar tingkat kemampuan sendiri sebelum tindakan tersebut dilakukan. Schutz menyebutkan adanya because motive sebelum terjadi in order to motive. Maksud dari because motive merupakan motif sebab yang mendasari suatu tindakan dari individu, motif inilah yang menjadi bahan pertimbangan dari individu, dimana individu itu akhirnya mengalami suatu perubahan dalam perubahan perilaku sosial dan masalah sosial. Sedangkan maksud 
dari in order to motive merupakan motif tujuan yang menjadi sasaran atau harapan dari individu ketika dirinya memilih untuk merokok. Pemaknaan dan kesadaran melakukan tindakan ini dilakukan oleh setiap aktor yang mencoba membangun pemahaman. Kehidupan aktor-aktor ini tidak pernah keluar dari dunia sosial yang ia miliki, sehingga dalam proses bertindak selalu terdapat bagian dimana kesadaran bertindak (act) atas data inderawi yang masih mentah, untuk menciptakan makna sehingga bisa melihat sesuatu yang bersifat mendua dari jarak tanpa masuk lebih dekat, mengidentifikasikannya melalui suatu proses dengan menghubungkannya dengan latar belakang.

\section{Metode Penelitian}

Penelitian ini menggunakan metode penelitian deskriptif kualitatif dengan pendekatan fenomenologi (Moleong 2014). Fenomenologi melihat dari because of motif merupakan motif sebab yang mendasari suatu tindakan dari individu, motif inilah yang menjadi bahan pertimbangan dari individu, dimana individu itu akhirnya mengalami suatu perubahan dalam perubahan perilaku sosial dan masalah sosial. Sedangkan maksud dari in order to motive merupakan motif tujuan yang menjadi sasaran atau harapan dari individu ketika dirinya memilih untuk merokok.

Lokasi penelitian dilakukan di Lingkungan Universitas Airlangga Surabaya Karena Surabaya merupakan salah satu kota besar dengan penduduk yang heterogen. Subyek dalam penelitian ini adalah mahasiswi yang merokok di Lingkungan Universitas Airlangga Surabaya, dengan teknik purposive, subyek penelitian ditentukan berdasarkan pertimbangan-pertimbangan tertentu misalnya telah menjadi perokok aktif dengan lama merokok lebih dari 2 (dua) tahun. Dengan batasan waktu informan merokok di area lingkungan kampus Universitas Airlangga Surabaya.

Teknik pengumpulan data menggunakan data primer dan sekunder. Data primer meliputi pengamatan berpartisipasi dan wawancara mendalam. Serta data sekunder yaitu sumber-sumber buku, skripsi terdahulu, jurnal, artikel, dokumen perempuan perokok dan sumber - sumber dari internet.

\section{Hasil dan Pembahasan}

\section{Merokok dipengaruhi oleh kondisi lingkungan sosial}

Merokok juga dapat dipengaruhi oleh kondisi lingkungan yang dimaksudkan yaitu meliputi lingkungan rumah, lingkungan keluarga, dan lingkungan pergaulan. Kebiasaan merokok dipengaruhi oleh berbagai faktor, baik internal maupun eksternal, di antaranya pendidikan orang tua, pengawasan yang kurang dari orang tua dan lingkungan sekitar, seperti saudara kandung dan teman akrab yang menyebabkan seseorang memutuskan untuk merokok. Selain itu, kebiasaan merokok pada perempuan dipengaruhi pula oleh pola hidup yang mulai bergeser. Asumsi bahwa perempuan yang merokok dianggap perempuan yang modern, seksi, glamor, matang dan mandiri juga merupakan salah satu faktor pemicu seorang perempuan memutuskan menjadi perokok. Tidak hanya itu saja, perempuan yang memiliki kebiasaan merokok biasanya menggunakan rokok sebagai alat pelarian dari masalah yang sedang dihadapinya. Mayoritas perempuan perokok berdalih bahwa dengan merokok bisa mengurangi atau bahkan menghilangkan stres dan bisa meringankan sedikit beban yang sedang mereka alami. Sehingga, setelah merokok mereka kadang bisa merasa nyaman dan lebih rileks dalam menyelesaikan permasalahan hidupnya.

Menurut Alfred Schultz sebuah kondisi ini merupakan adanya because motive sebelum terjadi in order to motive. Maksud dari because motive merupakan motif sebab yang mendasari suatu tindakan dari individu ketika dirinya memutuskan untuk merokok, motif inilah yang menjadi bahan pertimbangan dari individu, dimana individu itu akhirnya mengalami suatu perubahan dalam perubahan perilaku sosial dan masalah sosial. Sedangkan maksud dari in order to motive merupakan motif tujuan yang menjadi sasaran atau harapan dari individu ketika dirinya melilih cara sendiri untuk bersosialisasi dengan individu lain. Dalam kasus ini merokok adalah suatu tindakan dimana perempuan yang melakukannya sering kaitanya dianggap tabu dan kurang pantas (Ritzer \& Doughlas 2009). 
Berbagai fakta mengungkapkan bahwa semakin banyak teman sebayanya merokok maka semakin besar kemungkinan teman-temannya adalah perokok juga dan demikian sebaliknya. Terdapat dua kemungkinan yang terjadi dari fakta tersebut, pertama individu tersebut terpengaruh oleh temantemannya atau sebaliknya. Hal tersebut berarti bahwa positif dan negatif teman sebaya akan berpengaruh pada pembentukan identitas individu. Misalnya, individu yang cenderung bergaul dengan teman-teman sebayanya yang sering merokok ataupun minum-minuman keras akan sangat rentan untuk mengikuti gaya hidup mereka. Meskipun belum dinyatakan mutlak bahwa individu tersebut akan mengikuti gaya hidup teman-temannya namun perlu disadari bahwa masa muda merupakan masa ketidakstabilan, baik dalam pemikiran dan pemegangan prinsip hidup. Apalagi dengan rasa keingintahuan (eksplorasi) yang besar dan ingin mendapatkan pengakuan dari temanteman sebaya. Kelompok teman sebaya diakui dapat mempengaruhi pertimbangan dan keputusan individu tentang perilakunya. Walaupun individu tersebut telah mencapai tahap perkembangan kognitif yang memadai untuk menentukan tindakannya sendiri, namun penentuan diri seseorang dalam berperilaku banyak dipengaruhi oleh tekanan dari kelompok teman sebaya.

\section{Merokok sebagai bentuk kekecewaan/frustasi}

Di masa kini merokok merupakan suatu pemandangan yang sangat tidak asing. Kebiasaan merokok dianggap dapat memberikan kenikmatan bagi perokok, salah satu hal yang melatarbelakangi individu merokok adalah untuk menghilangkan kekecewaan dan menganggap perbuatannya tersebut tidak melanggar. Terlebih lagi pada individu atau kelompok masyarakat yang mengalami keadaan frustasi. Frustasi adalah keadaan kondisi di mana antara keadaan atau kondisi dan sistem sumber daya biologis, psikologis dan sosial yang ada pada individu mengalami ketidaksepadanan dan nyata atau tidak nyata.

Frustasi adalah tanggapan yang menyeluruh dari tubuh terhadap setiap tuntutan yang datang kepada individu. Frustasi pada dasarnya disebabkan oleh ketidakmengertian individu atas batasan-batasan tentang dirinya. Hal ini sejalan dengan kegiatan merokok yang dilakukan oleh individu di depan orang lain, terutama dilakukan di depan kelompoknya karena mereka sangat tertarik kepada kelompok atau dengan kata lain terikat dengan kelompoknya. Ketika individu dalam keadaan frustasi, seseorang tersebut lebih memilih suatu pemecahan masalah dengan mencoba hal baru yang kebanyakan bagi mereka dapat membuat dirinya merasa nyaman dan tenang. Akan tetapi cara mereka untuk mengatasi rasa kecewa juga berbeda-beda. Banyak yang melakukannya dengan hal-hal yang negatif akan tetapi juga banyak yang melampiaskan rasa frustasinya dengan hal yang positif. Ketika mengalami situasi demikian individu akan melihat suatu tindakan individu lain yang dirasanya akan membantu mengurangi atau bahkan menghilangkan rasa frustasi yang dialaminya. Meskipun tindakan tersebut tidak sesuai dengan norma dan peranan yang sedang dialami.

\section{Merokok sebagai cara pengalihan sebuah konflik}

Perilaku merokok lebih didasarkan atas pertimbangan emosional dari seorang individu ketika melihat berbagai permasalahan pada lingkungan keluarga. Individu yang sudah beranjak dewasa dan memiliki pemikiran sendiri terlebih lagi yang berpendidikan tinggi akan mengalami masa transisi kedewasaan yang lebih dari seorang individu biasa. Seiring dengan transisi itu kebanyakan orang tua tidak sadar akan perkembangan yang dialami oleh anak mereka.

Masalah-masalah keluarga antara sang ayah dan ibu sering kali dinampakan di depan mereka. Pengaruh orang tua sangat beser bagi perkembangan seorang individu, Menurut Alfred Schultz sebuah kondisi ini merupakan adanya because motive sebelum terjadi in order to motive. Pendidikan orang tua sangat berpengaruh penting pada perkembangan dan emosi seorang individu. Salah satu temuan tentang individu perokok adalah bahwa anak-anak muda yang berasal dari rumah tangga yang tidak bahagia, di mana orang tua tidak begitu memperhatikan anak-anaknya dan memberikan hukuman fisik yang keras lebih mudah untuk menjadi perokok dibanding anak-anak muda yang berasal dari lingkungan rumah tangga yang bahagia. Individu merokok apabila orangtua sendiri yang menjadi figur juga sebagai perokok berat, maka anak-anaknya mungkin sekali untuk mencontohnya. 


\section{Merokok sebagai hubungan pertemanan}

Perilaku merokok juga disebabkan oleh pengaruh kelompok teman sebaya. Kelompok teman sebaya seringkali menjadi faktor utama dalam masalah penggunaan rokok oleh individu. Selama masa remaja, seorang individu mulai menghabiskan lebih banyak waktu dengan teman sebayanya dari pada dengan orang tua. Hal ini berarti bahwa teman sebaya mempunyai peran yang sangat berarti bagi individu, karena remaja mulai bergabung dengan kelompok sebaya. Sikap teman sebaya terhadap penggunaan berbagai zat termasuk nikotin dapat mempengarui individu untuk menggunakan zat tersebut. Beberapa orang mulai mencoba rokok adalah untuk mengendalikan emosi seperti kecemasan kerja. Merokok mungkin dianggap dapat meningkatkan performansi dalam ujian dan memperbesar kesempatan seseorang untuk meraih prestasi akademik (Hurlock, 1987: 8).

Pengaruh kuat teman sebaya atau sesama remaja merupakan hal penting yang tidak dapat diremehkan dalam masa-masa remaja. Di antara pada individu terdapat jalinan yang kuat. Pada kelompok teman sebaya ini untuk pertama kalinya individu menerapkan prinsip-prinsip hidup bersama dan bekerja sama. Keberadaan teman sebaya sangat mempengaruhi tingkah laku, minat bahkan sikap dan pikiran remaja. Misalnya pengaruh terhadap cara berpakaian, gaya hidup, merokok dan sebagainya.

\section{Makna merokok sebagai sebuah kebutuhan yang tidak dapat ditinggalkan (candu)}

Rokok merupakan suatu hal yang wajib bagi sebagian masyarakat saat ini. Dari usia remaja hingga dewasa, dari jaman dulu sampai sekarang rokok tidak dapat ditinggalkan bahkan sudah menjadi salah satu kebutuhan. Tidak hanya sekedar kebutuhan bagi kaum laki-laki, semakin berkembangnya jaman rokok juga sudah menjadi kebutuhan kaum perempuan. Because of motive dalam fenomena ini terjadi dikarenakan oleh modernisasi yang secara tidak sengaja mulai menggeser pola berpikir dan budaya masyarakat sehingga tidak ada lagi ketabuan pandangan oleh masyarakat terhadap perempuan perokok. Dari sini dapat disimpulkan bahwa kebutuhan akan rokok sudah tidak bisa dilepaskan dari mereka. Sehingga in order to motive dari kebutuhan merokok bagi perempuan pada umumnya tergantung pada masing-masing individu yang menjadi perokok. Terjadi suatu tujuan yang menurut masing-masing individu tersebut berguna mengatasi ataupun membantu kondisi psikis seorang perokok perempuan. Terlebih lagi ketergantungan akan kebutuhan rokok bagi perempuan seolah-olah menjadi primer.

\section{Makna merokok sebagai lifestyle/gaya hidup}

Merokok tidak hanya sekedar bermakna sebagai hubungan pertemanan dan sebuah kebutuhan. Akan tetapi merokok juga dapat bermakna sebagai lifestyle atau gaya hidup bagi penikmatnya. Perkembangan kebutuhan hidup manusia yang dipicu oleh kemajuan ilmu pengetahuan dan teknologi terus mengalami perkembangan dari zaman ke zaman. Semakin banyaknya kebutuhan hidup manusia, semakin menuntut pula terjadinya peningkatan gaya hidup (lifestyle). Sebagai dampaknya, hal ini menuntut setiap orang untuk selalu up too date.

Banyak faktor yang dapat menjadi penyebab seorang perempuan menjadi perokok. Hampir semuanya menyatakan bahwa faktor lingkungan mempunyai andil yang sangat besar atas terbentuknya perilaku merokok dalam diri mereka. Misalnya faktor lingkungan pergaulan yang mampu merubah seorang yang bukan perokok menjadi perokok berat. Lingkungan pergaulan mempunyai pengaruh yang cukup kuat karena dalam kesehariannya seseorang selalu berinteraksi sosial dengan lingkungan pergaulan bersama teman-temannya.

Disamping lingkungan pergaulan, lingkungan keluarga juga turut mengambil bagian dalam hal pembentukan perilaku seseorang, dalam hal ini perempuan perokok. Terdapat satu informan mahasiswi perokok yang mengaku mulai tertarik untuk merokok setelah melihat sosok salah satu anggota keluarganya yang merokok. Sosok ini biasanya mempunyai pengaruh yang cukup kuat dalam diri individu tersebut Disamping itu, faktor yang mendorong seseorang untuk mencoba hal-hal baru termasuk merokok juga tidak bisa dikesampingkan begitu saja. Banyak perokok yang awalnya hanya 
coba-coba, tetapi kini malah menjadi pecandu berat. Selanjutnya, terdapat individu yang keinginan merokoknya berasal dari dalam dirinya sendiri karena mempunyai banyak hal yang dipikirkan. Jadi kebiasaan merokok yang mereka lakukan itu untuk menghilangkan stres atau hanya sekedar mengusir kejenuhan saja.

\section{Simpulan}

Motivasi yang mendasari mahasiswi mengkonsumsi rokok di antaranya adalah ingin coba-coba, motivasi dari dalam diri sendiri setelah melihat orang lain merokok, dan untuk menghilangkan stres. Terdapat berbagai pengaruh baik lingkungan keluarga dan pergaulan yang membuat mahasiswi kemudian memutuskan untuk menjadi perokok. Dari berbagai faktor itulah yang menyebabkan suatu kondisi atau keadaan di mana kebiasaan merokok pada perempuan hadir sebagai suatu tren baru dan sudah tidak dianggap tabu lagi oleh sebagian besar rnasyarakat.

Kebiasaan merokok akan diperkuat oleh anggapan bahwa perempuan merokok adalah sesuatu yang mengikuti perkembangan tren, seksi, glamor, matang, dan mandiri. Di samping itu kebiasaan merokok juga sejalan dengan pola hidup yang bergeser di mana rokok dipandang sebagai sebuah kebutuhan karena dinilai dapat menghilangkan stres.

\section{Daftar Pustaka}

Aditya NR (2019) Sejak Kapan Rokok Punya Gender? Dalam: https://mojok.co/terminal/sejak-kapanrokok-punya-gender/. Diakses 1 Oktober 2019.

Allen AM, Oncken C \& Hatsukami D (2014) Woman and smoking: The effect of gender on the epidemilogy, health effect, and cessation of smoking. Current Addiction Reports 1 (1):53-60.

Ayu P \& Syukur M (2018) Mahasiswi perokok di Kota Makassar. Jurnal Sosialisasi Pendidikan Sosiologi 5 (2):111-114.

Brahmana KM (2009) Gambaran Faktor-Faktor yang Mempengaruhi Wanita Dewasa Muda dalam Mengambi Keputusan Mengkonsumsi Rokok. Yogyakarta: Universitas Muhammadiyah Yogyakarta.

Buckner JD \& Vinci C (2013) Smoking and social anxienty: The roles of gender and smoking motives. Addictive Behaviors 38 (8):2388-2391.

Ellemers N (2018) Gender stereotypes. Annual Review Psychology 69:275-298.

Hagen EH, Garfield MJ \& Sullivan RJ (2016) The low prevalence of female smoking in the developing world: Gender inequality or maternal adaptations for fetal protection? Evolution, Medicine, and Public Health 2016 (1):195-211.

Hentschel T, Heilman ME \& Peus CV (2019) The multiple dimensions of gender stereotypes: A current look at men's and woman's characterizations of other and themselves. Fronties in Psychology 10:1-19.

Karini TA \& Padmawati RS (2018) Fenomena sosial unik pada perokok wanita di Kabupaten Lebong Bengkulu Indonesia. Berita Kedokteran Masyarakat 34 (1):19-24.

Kim HY, Kim KW, Kang MO \& Kim NH (2010) A phenomenological study on smoking experience in female adolescent. Journal Korean Acad Children Health Nurse 16 (1):10-19.

Komasari D \& Helmi AF (2000) Faktor-faktor penyebab perilaku merokok pada remaja. Jurnal Psikologi 1 (1):37-47.

Lestari Y \& Demartoto A (2012) Perempuan dan rokok (Kajian sosiologi kesehatan terhadap perilaku kesehatan reproduksi perempuan perokok di Kota Surakarta. Jurnal Promosi Kesehatan Indonesia 6 (1):67-77.

Lestari D (2012) Gambaran faktor-faktor yang menyebabkan remaja putri untuk merokok. Jurnal Penelitian dan Pengukuran Psikologi 1 (1):46-56.

Mansouri A, Kavi E, Ahmadpoori SF, Amin E, Bazrafshan MR, Piroozi A, Jokar M \& Zare F (2018) Cigarette smoking and coping strategies with stress in youg adult of Larestan. Jundishapur Journal Health Science 11 (1):1-7.

Moleong LJ (2014) Metode Penelitian Kualitatif. Bandung: PT Remaja Rosdakarya. 
Mustadjar M (2013) Sosiologi Gender. Makassar: Rayhan Intermedia.

Mutadhir AA \& Patasik JR (2018) perilaku merokok pada kaum perempuan (Studi kualitatif di masyarakat Desa Wondiboi, Kabupaten Teluk Wondama, Papua Barat). Jurnal Berkala Kesehatan 4 (1):30-39.

Purnomo A (2020) Diskriminasi Gender terhadap Perempuan Merokok oleh Lembaga Akademis. Dalam: https://komunitaskretek.or.id/opini/2020/01/diskriminasi-gender-terhadap-perempuanmerokok-oleh-lembaga-akademis/. Diakses 11 Januari 2020.

Ritzer G \& Doouglas G (2003) Teori Sosiologi Modern. Jakarta: Kencana.

Riyandi G, Wiyono J, \& Candrawati E (2017) Hubungan lingkungan sosial dengan perilaku merokok pada wanita di Kota Malang. Nursing News 2 (2):749-760.

Saguni F (2014) Pemberian stereotype gender. Musawa 6 (2):195-224.

Schutz A (1970) On Phenomenology and Social Relations. Chicago: The University of Chicago Press.

Septanto A (2019) Perilaku menyimpang masyarakat penjudi merpati di Surabaya. Jurnal Sosiologi Dialektika 14 (2):126-131.

Snow PC \& Bruce DD (2003) Cigarette Smoking in the Teenage Girl: Exploring th Role of Peer Reputatitons, self-concept, and coping. Oxford: Oxford University Press.

Thiangtham W, Kalampakorn S, Intharanate T \& Sornsin W (2013) The life experiences of thai woman and smoking: A phenomological study. Chotmaihet Thangphaet 9 (5):56-63.

Wulandari D (2007) Faktor-faktor yang mempengaruhi perilaku merokok dewasa awal. Jurnal Arkhe 2 (2):91-100. 